\title{
Effect of Intercropping of Some Oil Summer Crops with Maize under Levels of Mineral N and Nano N Fertilizers
}

\author{
${ }^{1}$ A.E. El-Karamity, ${ }^{2}$ Nagwa R. Ahmed ${ }^{*}$ and ${ }^{1}$ Aya N. Mohamed \\ ${ }^{1}$ Agronomy Dept. Fac. of Agric. Minia University, Egypt. \\ ${ }^{2}$ Crop Intensification Res. Dept., Field Crops Res. Inst., ARC, Giza, Egypt. \\ *Corresponding author mail: drnagwarefat2014@gmail.com
}

Received on: 14/9/2020

Accepted on: 31/10/2020

\begin{abstract}
In Egypt, we have a big gap between our production and consumption of edible oil accounted by more than $95 \%$. In recent few years many attempts and efforts were pushed to increase our production, one of these attempts is intercropping of oil summer crops with maize to increase the production in addition to provide the soil with natural nitrogen. Therefore, two field experiments were carried out at Mallawi Agricultural Research Station, Minia, ARC, during 2018 and 2019 seasons, to study the effect of intercropping three oil crops on productivity, quality and profitability of maize and using different rates of $\mathrm{N}$ nano + mineral fertilizer A complete Randomized Block Design in a split plot arrangement. Main plots were devoted for the following soybean, groundnut and sesame $50 \%$ of the recommended. The following rates of fertilizer, $100 \% \mathrm{~N}$ mineral fertilizer, $100 \% \mathrm{~N}$ nano fertilizer,75\% nano+25\% mineral fertilizer, $50 \%$ nano $+50 \%$ mineral fertilizer and $25 \%$ nano+ $75 \%$ mineral fertilizer added for maize and three oil crops from recommended does were allocated in the sub- plots. The intercropping groundnut with maize gave the highest values of grain yield $(23.25 \& 21.61) \mathrm{ardab} / \mathrm{fad}$ in the both seasons respectively. The intercropping groundnut with maize and using $75 \% \mathrm{~N}$ nano fertilizer $+25 \% \mathrm{~N}$ mineral fertilizers recorded the highest values for land Equivalent Ratio (LER). The pattern of maize- 50\% groundnut intercrop fertilized with $75 \%$ nano fertilizer $\mathrm{N}+25 \%$ mineral fertilizer $\mathrm{N}$ of the recommended for maize were more profitable for farmer.
\end{abstract}

KEYWORDS: Nano fertilizer, intercropping, sesame, groundnut, LER, oil crops.

\section{INTRODUCTION}

Oilseed crops are not only oil producing crops but also income generation crops. Groundnut (Arachis hypogeae L.) ranks with each of soybean, rapeseed and sunflower as four of the most important annual crops in the world grown for edible oil. They are the promising oil seed crops which can play an important role in increasing edible oil production in Egypt. The use of corn oil is also gaining momentum where large volumes of maize are used in ethanol production. Companies are developing and improvements of crude corn oil to facilitate conversion into biodiesel (FAO, 2016). Sesame oil is of good quality, and according to, the oil is used for cooking, baking, candy making, soaps and alternative medicine (in the control of blood pressure, stress and tension). (Kafiriti and Deckers 2001; Alam et al., 2007).

Maize (Zea mays L.) is the third largest cereal crop in the country. Maize is used primarily for food for humans and feed for livestock. It is important in the development of starch, oil and alcohol in the industry (Kling and Edmeades, 1997).

Intercropping decreased the number of pods and component groundnut grain yields. With increased planting density, the number of pods and grain yields grew. Productivity indices indicated that intercropping of groundnut / maize was efficient;
Intercropping reduced the number of pods and grain yields of the groundnut portion. The number of pods and grain yields increased with an increased density of planting. Productivity indices indicated that groundnut / maize intercropping was productive and that maize was the dominant portion. The marginal rate of return for the best combinations was 116.13 per cent, indicating the viability of intercropping systems (Godwin and Egbe 2014; Metwally et al., 2005 a,b and Sheriff et al., 2005).

Maize-sesame intercropping is considered to be effective due to the risk of loss of sesame output associated with pure sesame development. Growing intercrop also places less pressure on labor and fertile land, both of which are restricted in supply. In addition, maize and sesame are considered healthy companion crops, which additionally contribute to the restoration of soil fertility and weed suppression (Mkamilo, 2004).

Systems that intercrop maize with legumes are capable of decreasing the amount of nutrients taken from the soil relative to maize monocrops. Once nitrogen fertilizer is applied to the field, intercropped legumes use inorganic nitrogen instead of nitrogen from the air and thus compete with maize for nitrogen. However, when nitrogen fertilizer is not used, intercropped legumes can release much of their nitrogen from the atmosphere and will not compete 


\section{A.E., El-Karamity et al., 2020}

with maize for nitrogen supplies (Adu-Gyamfi et al., 2007).

Nano fertilizers are valuable tools in agriculture to increase crop growth, yield and quality parameters by increasing the efficiency of nutrient usage, reducing fertilizer waste and the cost of cultivation. Nano-fertilizers increase crop growth before optimum concentrations increase more concentration can inhibit crop growth due to the toxicity of the nutrient. Nano-fertilizers provide more surface area for different metabolic reactions in the plant, which increase the photosynthesis and prophylaxis process (Rameshaiah et al., 2015 and Meena et al., 2017). Nitrogen (N) has been better used in nano-fertilizer treatments than in traditional fertilizer treatments, suggesting that there is a nanofertilizer variety in crop agriculture. However, using this at the farmer's level would require a pilot scale fertilizer synthesis. Study showed a higher accumulation of $\mathrm{N}$ in plants grown with nano fertilizers. Post-effect Nano Fertilizer application in soil showed better $\mathrm{pH}$, moisture, $\mathrm{CEC}$ and usable nitrogen under nano-fertilizer treatment than (Anjuman et al.,2016). Nano-fertilizers are known to release nutrients slowly and steadily for more than $\mathbf{3 0}$. days which may assist in improving the nutrient use efficiency without any associated ill-effects. Since the nano-fertilizers are designed to deliver slowly over a long period of time, the loss of nutrients is substantially reduced vis-a-vis environmental safety. The work done on nano-fertilizers is very limited across the globe, but the reported literature clearly demonstrated that these customized fertilizers have a potential role to play in sustaining farm productivity (Sekhon, 2014 and Siddiqui et al., 2015). Development, yield, quality and nutrient uptake of maize were consistently higher for nanozeourea (nanozeolite-coated urea) treatment than traditional urea (Manikandan and Subramanian, 2016). Hasaneen et al., (2016) demonstrated that nanomaterials are leading to significant improvement in plant through enhancing the growth and hence dry weight, leaf area and growth rate.Nano fertilizer has a positive significant effect on soil mineral nitrogen, due to available by plant. Post-effect nano-fertilizer application in soil showed better $\mathrm{pH}$, moisture, EC and usable nitrogen under nano-fertilizer treatment than traditional fertilizers. Nano fertilizer, the most important field of agriculture, has attracted the attention of soil scientists as well as environmentalists due to its ability to increase yield, enhance soil fertility, minimise contamination and create a favorable environment for microorganisms (Ahmed et al., 2012).

The highest values of these study characters were obtained with $75 \%$ nano fertilization NPK + $25 \%$ mineral fertilization NPK fed ${ }^{-1}$. There was consistent and remarkable increase in ear characters by increasing nano fertilizer. Maize grain yield behaved in parallel trended as yield components (Nagwa et al., 2019). Maize with soybean had significant advantage in yield, economy, land utilization ratio and reducing soil nitrate nitrogen $(\mathrm{N})$ accumulation (Yitao et al., 2015). Land equivalent ratio without significant reduction in maize yield /fad. LER ranged from 1.81 to 1.56 (Sherif 2010$) 75 \%$ of recommended dose of mineral $\mathrm{N}$ along with $25 \%$ nano urea, increased productivity of maize by 17.03 and $14.11 \%$ compared with mineral fertilization (Ijoyah et al., 2014; Yasser et al., 2020). The productivity of maize-cropping systems can be improved by intercropping soybean between maize plants as confirmed by high LER. MAI was positive for all intercrops in both locations and years, which shows definite yield and economic advantages compared to the sole cropping systems tested. (Alpha et al.,2017).

The objective of this research was to study the response of summer oil crops i.e., soybean, groundnut and sesame to intercrop with maize and applied fertilizer $\mathrm{N}$ nano fertilizer particles does for achieving success under intercropping conditions on the yield and its components under Middle Egypt conditions.

\section{MATEREALS AND METHODES}

A field experiments were conducted at Mallawi Agricultural Research Station, Minia Governorate, ARC, during two summer seasons of 2018 and 2019. Maize cv. Giza 168 (yellow corn), soybean (Giza111), groundnut (Giza 6) and sesame (Shindauel 3) were used in this study. These experiments were laid out in split - plot arrangement using Randomized Complete Blocks Design with three replicates. The sub - plot area was $28 \mathrm{~m}^{2}$ consisting of 5 beds, each of bed was $140 \mathrm{~cm}$ in width and, $4 \mathrm{~m}$ in length.

The main plots were devoted to the three intercropping oil summer crops, soybean, groundnut and sesame with maize.

A $1-100 \%$ maize $+50 \%$ soybean from recommended. A2- $100 \%$ maize $+50 \%$ groundnut from recommended.

A3- $100 \%$ maize $+50 \%$ sesame from recommended. The sub-plots were occupied by the levels of mineral and nano particles of $\mathrm{N}$ fertilization.

$\mathrm{F} 1-100 \%$ mineral fertilizer $\mathrm{N}$ of maize from recommended.

F2- $100 \%$ Nano particles $\mathrm{N}$ fertilizer of maize from recommended.

F3- $75 \%$ Nano particles $\mathrm{N}+25 \%$ mineral $\mathrm{N}$ fertilizer of maize from recommended.

F4-50\% Nano particles $\mathrm{N}+50 \%$ mineral $\mathrm{N}$ fertilizer of maize from recommended.

F5- 25\%Nano particles $\mathrm{N}+75 \%$ mineral $\mathrm{N}$ fertilizer of maize from recommended.

Amount of $\mathrm{N}$ nano fertilizer utilization equal 1/3 amount recommended dose nitrogen for maize and three oil crops. 
Solid plots of maize and three oil summer crops, soybean, groundnut and sesame were also included in each replication for comparison and determination of the competitive relationships and to calculate the yield advantage of crops, total income and net return fad. Maize was planted on two sides of beds with one plant/ hill at $25 \mathrm{~cm}$ apart in all intercropping patterns (24.000plant/fad). The three oil crops were planted in the center of the bed and were sown two rows for oil crops, two plant/hill at $20 \mathrm{~cm}$ between hills (70.000 plant/fad) for soybean, one plant / hill at $20 \mathrm{~cm}$ between hills for sesame (35.000 plant/fad) and one plant /hill at $20 \mathrm{~cm}$ between hills (35.000 plant/fad) for groundnut. Oil crops were seeded before maize on May $15^{\text {th }}$ and $18^{\text {th }}$ in 2018 and 2019seasones, respectively. Maize plants were planted one side of ridges as pure stand and oil crops pure were planted as recommended. Plants maize was seeded onJune $6^{\text {th }}$ and $9^{\text {th }}$ in 2018 and 2019 seasons, respectively. The preceding crop was onion in both seasons. Normal cultural practices were applied for crops under study either in pure stand or in intercropping as recommend for the region. Nano fertilizers were prepared in laboratory by ball-milling (Photon Company, Egypt). The size and morphology of nano particles were studied using transmission electron microscope (JEM1400 TEM, Japan). The average size $5.42 \mathrm{~nm}$ nano-particle with a range from 4.42 to $8.42 \mathrm{~nm}$. The obtained investigated $\mathrm{N}$ fertilizes data showninFig. 1.

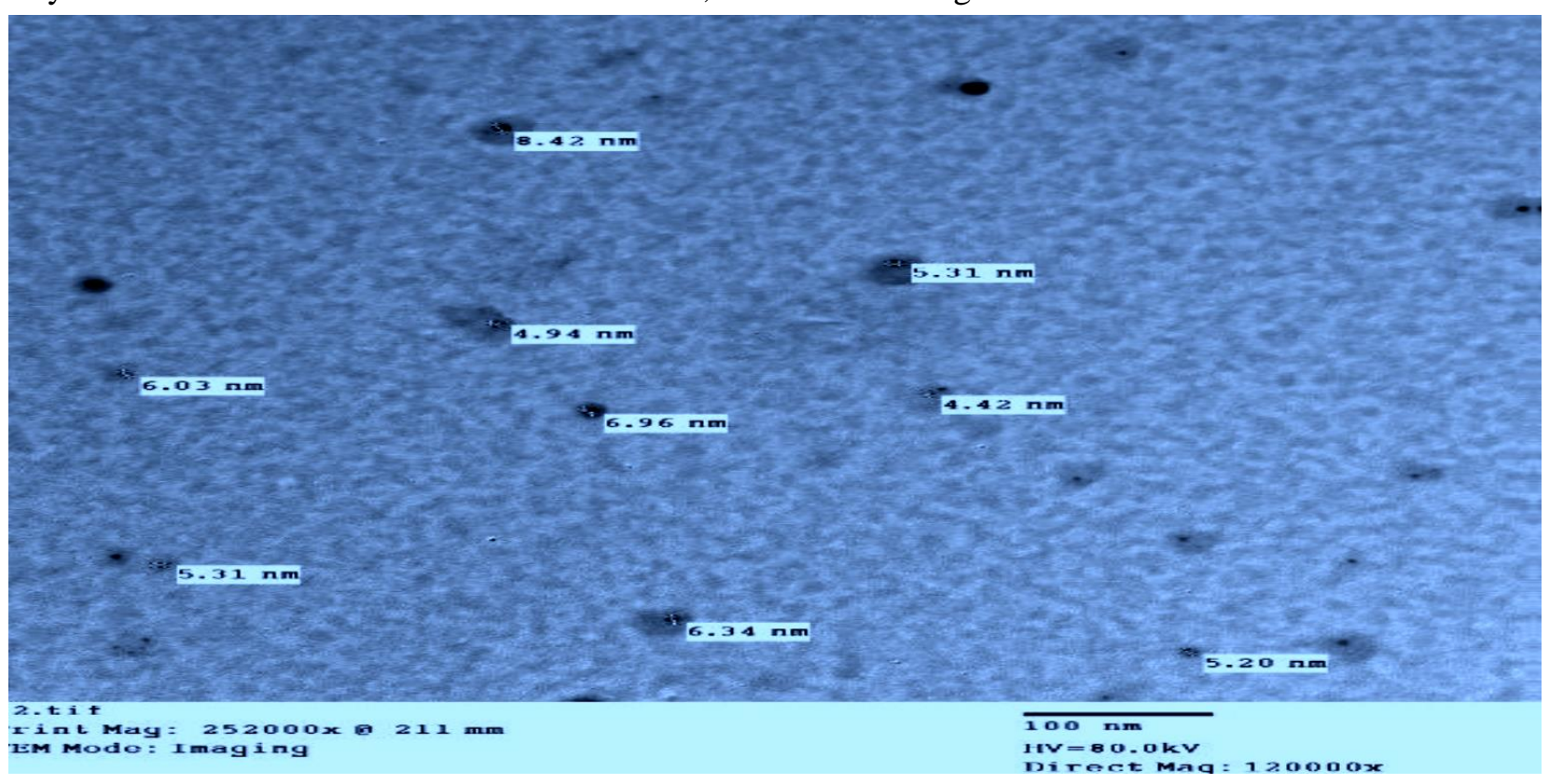

Fig. 1. Transmission electron microscopy (TEM) micrograph of synthesized $\mathrm{N}$ nano

Nano fertilizers as spraying on soil application at two times i.e., after 30 and 45 days from sowing. However, nitrogen fertilizer was applied as ammonium nitrate $(33.5 \% \mathrm{~N})$ at a rate $100 \mathrm{~kg} \mathrm{~N}$ fad in three equal doses jest before the first, second and irrigation of maize. Calcium super phosphate $\left(15 \% \mathrm{P}_{2} \mathrm{O}_{5}\right)$ at a rate of $150 \mathrm{~kg} \mathrm{fed}^{-1}$.was added during preparation the land for sowing. Potassium fertilizer was applied before sowing (during seeded preparation) at rate of $50 \mathrm{~kg} / \mathrm{fed}$., in the form of potassium sulphate $\left(48 \% \mathrm{~K}_{2} \mathrm{O}\right)$. All other agricultural practices for maize and oil crops production was carried out as recommended by the Ministry of Agriculture.

\subsection{The studied traits:}

2.2.1. maize: At harvest time 110 days after sowing, the following traits were measured on ten guarded plants, plant height $(\mathrm{cm})$, stem diameter $(\mathrm{cm})$ ear height $(\mathrm{cm})$, ear length and diameter $(\mathrm{cm})$, number of grain and ear weight $(\mathrm{g})$, grain yield / plant $(\mathrm{g}), 100$ weight grain $(\mathrm{g})$, number of ears / plant and grain yield $\operatorname{ardab} / \mathrm{fad}(\operatorname{ardab}=140 \mathrm{~kg})$.
2.2.2. Soybean: At harvest time 120 days after sowing, the following traits were measured on ten guarded plants i.e. plant height $(\mathrm{cm})$ number of fruiting branches/plant number of pods, seed index, seed yield ( $\mathrm{kg} / \mathrm{fad})$ and Straw yield (ton /fad).

2.2.3. Groundnut: At harvest time 140 days after sowing, the following traits were measured on ten guarded plants, plant height $(\mathrm{cm})$ number of fruiting branches, number of pods, seed index, pods yield $\mathrm{ardab} / \mathrm{fad}(\mathrm{ardab}=75 \mathrm{~kg})$ and green yield ton $/ \mathrm{fad}$.

2.2.4. Sesame: At harvest time 100 days after sowing, the following traits were measured on ten guarded plants, plant height $(\mathrm{cm})$ and length of fruiting zone $(\mathrm{cm})$, no. of capsule/plant, seed index and seed yield ardab $/$ fad $(\operatorname{ardab}=120 \mathrm{~kg})$.

\subsection{Competitive relationships and yield} advantages:

2.3.1. Land Equivalent Ratio (LER) was calculated according to (Willey 1979) using the following formula: $\mathrm{LER}=\mathrm{yab} / \mathrm{yaa}+\mathrm{yba} / \mathrm{ybb}$ 


\section{A.E., El-Karamity et al., 2020}

Where: $Y a a=$ pure stand yield of species a (maize). $\mathrm{Ybb}=$ pure stand yield of species (b). Yab = mixture yield of a (when combined with $b$ )

Yba $=$ mixture yield of $b$ (when combined with $a$ ).

2.3.2. Land Equivalent Coefficient (LEC) is a measure of interaction concerned with the strength of relationship (Adetiloye $\boldsymbol{e t} \boldsymbol{a l}$., 1983). It is calculated as follows: $\mathrm{LEC}=\mathrm{La} \times \mathrm{Lb}$

Where La $=$ LER of crop a (maize), Lb = LER of crop b (intercropping crops).

2.3.3. Competitive ratio (CR) was calculated by the following formula as given by Willey and Rao (1980). $\quad \mathrm{CR}=\mathrm{CRa}+\mathrm{CRb}$

$\mathrm{CRa}=\mathrm{LERa} / \mathrm{LER}$ b X Zba/ Zab

Where: LERa and LERb represent relative yield of a, $b$ intercrops respectively. Since the CR values of the two crops will in fact be reciprocals of each other. $\mathrm{CRa}, \mathrm{CRb}$ are the competitive ratio for (a) and (b) intercropping.

2.3.4. Aggressivity (Agg): This was proposed by McGilichrist (1965) and was determined according to the following formula:

$\mathrm{Aab}=\mathrm{Yab} /$ yaax zab $-\mathrm{Yba} / \mathrm{ybb} \mathrm{x}$ zba. An aggressivity value of zero indicates that the component crops are equally competitive. For any other situations both crop will have the same numerical value but, the high of the dominant crop is positive and the dominated is negative. The greater numerical value of (Agg), gave greater difference in competitive abilities and hence the larger difference between actual and expected yield. Where Zab representing the sown proportion of intercrop a (soybean, groundnut and sesame) in combination

Table 1. Some physical and chemical properties with (maize) and zba the sown proportion of intercrop a (maize) in combination with b (soybean, groundnut and sesame).

2.3.5. Monetary advantage index (MAI): Suggests that the economic assessment should assess on the basis of the rentable value of this land. MAI was calculated according to the formula suggested by Willey (1979).

MAI $=$ Value of combined intercrops $x$ LER-

$1 / \mathrm{LER}$

2.3.6. Farmer's benefit: It was calculated by determining the total costs and net return of intercropping culture as compared to recommended solid planting of maize as follows: Total return of intercropping cultures $=$ Price of maize yield + price of intercropping pattern yield. To calculate the total return, the average of soybean, groundnut and sesame prices presented by Agriculture Statistics (2017 and 2018) seasons was used.

Net return per fed. $=$ Total return - (fixed costs of maize + variable soybean, groundnut and sesame according to intercropping pattern). L.E 480 for ardab of maize; L.E 7000 for ton of soybean, L.E 1200 for ardab groundnut and L.E 3000 for ardab sesame.

\subsection{Statistical analysis:}

All data were statistically analyzed using analysis of variance (ANOVA) with the Statistical Analysis System MSTAT-C Statistical Packing (Freed 1991). Probabilities equal to or less than 0.05 were considered significant. If ANOVA indicated differences between treatment means LSD test was performed according to (Steel and Torrie 1980).

the soil of experiment site during 2018 and 2019 seasons.

\begin{tabular}{cccccccc}
\hline Properties & Sand \% & Silt\% & Clay \% & pH & EC & CaCo 3\% & O. M \% \\
\hline $1^{\text {st }}$ season & 9.81 & 38.83 & 51.36 & 8.01 & 1.73 & 1.80 & 1.60 \\
$2^{\text {nd }}$ season & 10.69 & 40.26 & $\begin{array}{c}49.05 \\
\text { Salty clay loam }\end{array}$ & 8.05 & 1.76 & 1.74 & 1.66 \\
Soil texture & \multicolumn{7}{c}{ Available nutrient } \\
\hline \multicolumn{7}{c}{ P ppm } \\
\hline $1^{\text {st }}$ season & 0.19 & 20 & & K mm \\
$2^{\text {nd }}$ season & 0.20 & 22 & 350 & 370 \\
\end{tabular}

E.C = Electric conductivity $(\mathrm{ds} / \mathrm{m}, 1: 5$ soil water extract $) . \mathrm{O} . \mathrm{M}=$ Organic matter.

\section{RESULTS AND DISCUSSION}

\subsection{Maize:}

\subsubsection{Effect of intercropping oil crops on maize:}

The tabulated results in Table (2) indicated that intercropping of soybean, groundnut and sesame with maize had a significant effect on plant height, grain weight /plant (g) and grain yield (ardab/fad) in the two summer seasons and ear height, ear length and ear diameter in the $2^{\text {nd }}$ season. Intercropping groundnut with maize gave the highest values of all characters under study while intercropping sesame with maize gave the lowest values of all characters in the $1^{\text {st }}$ and $2^{\text {nd }}$ seasons. Intercropping groundnut with maize gave the highest values of grain yield $(23.25 \& 21.61 \mathrm{ardab} / \mathrm{fad})$ in the $1^{\text {st }}$ and $2^{\text {nd }}$ seasons, respectively, which due to increase the yield components. Whereas sesame intercropping with maize gave the lowest values of grain yield (20.69 $\& 17.40 \mathrm{ardab} / \mathrm{fad})$ in the both seasons, respectively. Densities of groundnut had no effect, on yield of maize /fad as compared with sesame. maize-legume intercropping, the maize is more competitive than the 
legume under high soil $\mathrm{N}$ conditions (This is mostly due to the ability of legumes to fix $\mathrm{N} 2$ and the apparent reduced competition for radiation between the intercrop components in poorly fertile fields leading to reduced shading of the legume by the intercropped maize crop, to the benefit of corn as a quadruple carbon crop. In addition, peanuts have less competition with corn because of the smaller group of vegetative growth than soybean or sesame. These results are accordance with those obtained by (Mohamed 2007; Sherif 2010; yu et al., 2016 and Michael et al., 2017). Soybean has good effect on soil fertility and physiological properties, therefore significant amount of residual nitrogen for maize plants and encourage maize growth characteristics (Toaima, 2006).

Table 2. Yield traits of intercropped maize with soybean, groundnut, and sesame as affected by $\mathbf{N}$ mineral fertilization and $N$ nano fertilizer rate of maize 2018 and 2019 cropping seasons.

\begin{tabular}{|c|c|c|c|c|c|c|c|c|c|c|c|}
\hline \multirow{2}{*}{$\begin{array}{l}\text { Intercropping } \\
\text { Pattern. } \\
\text { (A) }\end{array}$} & \multirow{2}{*}{$\begin{array}{c}\text { Plant } \\
\text { height } \\
(\mathbf{c m})\end{array}$} & \multirow{2}{*}{$\begin{array}{l}\text { Stem } \\
\text { Dime. } \\
(\mathrm{cm})\end{array}$} & \multirow{2}{*}{$\begin{array}{c}\text { Ear } \\
\text { Height } \\
\text { (cm) }\end{array}$} & \multicolumn{2}{|c|}{ Ear } & \multirow{2}{*}{$\begin{array}{l}\text { No of } \\
\text { grain } \\
\text { ear }\end{array}$} & \multirow{2}{*}{$\begin{array}{l}\text { Weight } \\
\text { ear } \\
\text { (g) }\end{array}$} & \multirow{2}{*}{$\begin{array}{c}\text { Grain } \\
\text { weight } \\
\text { /plant } \\
\text { (g) }\end{array}$} & \multirow{2}{*}{$\begin{array}{c}100 \\
\text { weigh } \\
\mathbf{t} \\
\text { Grai } \\
\mathbf{n} \\
(\mathrm{g}) \\
\end{array}$} & \multirow{2}{*}{$\begin{array}{c}\text { No of } \\
\text { ears } \\
\text { /plant }\end{array}$} & \multirow{2}{*}{$\begin{array}{c}\text { Grain } \\
\text { yield } \\
\text { ardab/ } / \\
\text { fad }\end{array}$} \\
\hline & & & & $\begin{array}{c}\text { Length } \\
(\mathbf{c m})\end{array}$ & $\begin{array}{c}\text { Dimater } \\
(\mathbf{c m})\end{array}$ & & & & & & \\
\hline \multicolumn{12}{|c|}{2018 season } \\
\hline $\begin{array}{l}\mathrm{M}+50 \% \\
\text { soybean }\end{array}$ & 255.24 & 1.93 & 150.13 & 26.37 & 4.39 & 662.74 & 268.87 & 234.33 & $\begin{array}{c}32.0 \\
0\end{array}$ & 1.12 & 21.85 \\
\hline $\begin{array}{l}\text { M+50\% } \\
\text { groundnut }\end{array}$ & 261.07 & 1.98 & 153.20 & 28.27 & 4.45 & 699.47 & 282.92 & 250.26 & $\begin{array}{c}34.4 \\
8\end{array}$ & 1.18 & 23.25 \\
\hline $\begin{array}{c}\mathrm{M}+50 \% \\
\text { sesame }\end{array}$ & 250.53 & 1.86 & 148.00 & 25.40 & 4.31 & 566.08 & 277.10 & 225.43 & $\begin{array}{c}30.2 \\
0\end{array}$ & 1.13 & 20.69 \\
\hline L.S.D 5\% & 5.70 & N.s & N.s & N.s & N.s & N.s & N.s & 44.62 & N.s & N.s & 1.21 \\
\hline \multirow{2}{*}{\multicolumn{12}{|c|}{$24.48 \mathrm{ardab} / \mathrm{fad}$}} \\
\hline & & & & & & & & & & & \\
\hline $\begin{array}{l}\text { M+50\% } \\
\text { soybean }\end{array}$ & 210.27 & 1.88 & 127.89 & 20.82 & 4.60 & 612.42 & 220.13 & 185.74 & $\begin{array}{c}30.8 \\
7\end{array}$ & 1.00 & 19.76 \\
\hline $\begin{array}{l}\text { M+50\% } \\
\text { groundnut }\end{array}$ & 216.55 & 1.91 & 131.63 & 21.42 & 4.70 & 632.33 & 223.24 & 208.57 & $\begin{array}{c}31.4 \\
0\end{array}$ & 1.146 & 21.61 \\
\hline $\begin{array}{c}\mathrm{M}+50 \% \\
\text { sesame }\end{array}$ & 204.49 & 1.78 & 127.65 & 20.29 & 4.60 & 581.26 & 218.23 & 177.24 & $\begin{array}{c}30.2 \\
7 \\
\end{array}$ & 0.96 & 17.40 \\
\hline L.S.D 5\% & 6.39 & N.s & 5.36 & 1.81 & 0.19 & N.s & N.s & 30.56 & N.s & N.s & 1.87 \\
\hline Solid maize & \multicolumn{11}{|c|}{$22.14 \mathrm{ardab} / \mathrm{fad}$} \\
\hline
\end{tabular}

\subsubsection{Effect of $N$ mineral and nano particles} fertilizer rates on maize:

Data presented in Table 3 revealed the effect of spraying on soil application of nano and mineral fertilizer on maize and companion crops. Plant height, stem and ear diameter are an important vegetative growth parameter of maize plant that are directly influenced by nano fertilizer. The data over seasons (Table3) revealed number significant differences among the different applications of nano and mineral fertilizer for ear weight $(\mathrm{g})$ and number of ears/plant in the $2^{\text {nd }}$ season. While, significant differences were found among the different applications for the all other characters. Plant height, stem diameter, ear length, ear diameter, ear weight yield, grain / plant and grain yield/fad recorded the highest values under the application of $75 \%$ nano fertilizer $\mathrm{N}+25 \% \mathrm{~N}$ mineral fertilization of maize. The lowest values for the studied characters were recorded when application of $100 \%$ mineral fertilization $\mathrm{N}$ of maize. (Suppan 2017 and Meena et al., 2017) reported that, nano fertilizer enhance the yield components such as plant height, stem diameter, ear diameter etc., though, increasing the meristematic activity and stimulation of cell elongation in plants. 
A.E., El-Karamity et al., 2020

Table 3. Yield traits of maize as affected by $\mathrm{N}$ mineral and $\mathrm{N}$ nano fertilization 2018 and 2019 cropping seasons.

\begin{tabular}{|c|c|c|c|c|c|c|c|c|c|c|c|}
\hline \multirow{2}{*}{$\begin{array}{r}\text { Fertilzer. } \\
\text { (B) }\end{array}$} & \multirow{2}{*}{$\begin{array}{l}\text { Plant } \\
\text { height } \\
(\mathrm{cm})\end{array}$} & \multirow{2}{*}{$\begin{array}{l}\text { Stem } \\
\text { Dimet. } \\
(\mathrm{cm})\end{array}$} & \multirow{2}{*}{$\begin{array}{l}\text { Ear } \\
\text { Height } \\
(\mathrm{cm})\end{array}$} & \multicolumn{2}{|l|}{ Ear } & \multirow{2}{*}{$\begin{array}{l}\text { No of } \\
\text { grain } \\
\text { ear }^{-1}\end{array}$} & \multirow{2}{*}{$\begin{array}{l}\text { Weight } \\
\text { Ear } \\
(\mathrm{g})\end{array}$} & \multirow{2}{*}{$\begin{array}{l}\text { Grain } \\
\text { weight } \\
\text { /plant } \\
\text { (g) } \\
\end{array}$} & \multirow{2}{*}{$\begin{array}{l}100 \\
\text { weight } \\
\text { Grain } \\
\text { (g) }\end{array}$} & \multirow{2}{*}{$\begin{array}{l}\text { No of } \\
\text { ears } \\
\text { /plant }\end{array}$} & \multirow{2}{*}{$\begin{array}{l}\text { Grain } \\
\text { yield } \\
\text { ardab/ } \\
\text { fad }\end{array}$} \\
\hline & & & & $\begin{array}{l}\text { Length } \\
\text { (cm) }\end{array}$ & $\begin{array}{l}\text { Dimater } \\
(\mathrm{cm})\end{array}$ & & & & & & \\
\hline \multicolumn{12}{|c|}{2018 season } \\
\hline N nano :1 & 253.0 & 1.82 & 144.89 & 23.94 & 4.32 & 520.80 & 263.0 & 187.65 & 29.00 & 1.16 & 16.19 \\
\hline$+\mathrm{N} \quad \mathrm{B} 2$ & 255.18 & 1.87 & 146.33 & 25.17 & 4.37 & 583.28 & 273.50 & 233.56 & 31.00 & 1.13 & 21.34 \\
\hline mineral :3 & 263.89 & 2.06 & 157.44 & 29.33 & 4.49 & 818.08 & 305.97 & 267.5 & 36.06 & 1.15 & 26.33 \\
\hline fertilizer :4 & 254.56 & 1.93 & 152.89 & 28.00 & 4.37 & 663.04 & 289.56 & 253.33 & 33.30 & 1.12 & 24.17 \\
\hline$: 5$ & 251.44 & 1.90 & 150.67 & 26.94 & 4.35 & 628.61 & 281.61 & 241.33 & 32.11 & 1.15 & 21.63 \\
\hline L.S.D 5\% & 5.75 & 0.11 & 3.51 & 1.20 & 0.080 & 65.64 & 34.00 & 29.31 & 2.52 & 0.14 & 2.70 \\
\hline \multicolumn{12}{|c|}{$24.48 \mathrm{ardab} / \mathrm{fad}$} \\
\hline \multicolumn{12}{|c|}{2019 season } \\
\hline N nano :1 & 204.44 & 1.54 & 124.10 & 19.18 & 4.36 & 526.70 & 188.48 & 157.67 & 27.78 & 0.89 & 13.73 \\
\hline$+\mathrm{N}: 2$ & 210.92 & 1.82 & 125.89 & 20.44 & 4.53 & 572.75 & 204.79 & 171.14 & 29.56 & 0.90 & 19.59 \\
\hline mineral i3 & 215.56 & 2.03 & 134.78 & 22.72 & 4.88 & 678.33 & 256.31 & 228.72 & 34.11 & 1.40 & 25.24 \\
\hline fertilizer :4 & 212.33 & 1.97 & 131.48 & 21.47 & 4.82 & 647.04 & 235.16 & 206.14 & 32.00 & 1.00 & 20.62 \\
\hline 15 & 208.92 & 1.94 & 129.05 & 20.40 & 4.60 & 618.53 & 217.94 & 188.89 & 30.78 & 0.90 & 18.77 \\
\hline L.S.D 5\% & 5.60 & 0.11 & 5.01 & 1.74 & 0.22 & 71.60 & N.s & 25.52 & 2.90 & N.s & 3.78 \\
\hline
\end{tabular}

B1: $100 \%$ mineral fertilization $\mathrm{N}$ of maize

B2: $100 \%$ Nanotechnology fertilization $\mathrm{N}$ of maize

B3: $75 \%$ Nanotechnology fertilization $\mathrm{N}+25 \%$ mineral fertilization $\mathrm{N}$ of maize

B4: $50 \%$ Nanotechnology fertilization $\mathrm{N}+50 \%$ mineral fertilization $\mathrm{N}$ of maize

B5: $25 \%$ Nanotechnology fertilization $\mathrm{N}+75 \%$ mineral fertilization $\mathrm{N}$ of maize

Maize grain yield behaved in parallel way with yield components in the two seasons (Table3). The application of $75 \%$ nano fertilizer $\mathrm{N}+25 \% \mathrm{~N}$ mineral fertilization of maize gave the highest values of grain yield ( $26.33 \& 25.24 \mathrm{ardab} / \mathrm{fad})$ in the $1^{\text {st }}$ and $2^{\text {nd }}$ seasons, respectively, via increasing yield component. Whereas the application of $100 \% \mathrm{~N}$ mineral fertilization of maize gave the lowest values of grain yield ( $16.19 \& 13.73 \mathrm{ardab} / \mathrm{fad})$ in the 1 st and 2 nd seasons, respectively. Nano-fertilizers provide more surface area for different metabolic reactions in the plant which increase rate of photosynthesis and produce more dry matter and yield of the crop. It is also preventing plant from different biotic and a biotic stress. Nitrogen $(\mathrm{N})$ was better in nano fertilizer treatments than in the conventional fertilizer treatments indicating the fact that there is a scope of nano-fertilizer in crop agriculture. (Rameshaiah et al., 2015; Meena et al., 2017 and Yasser et al., 2020).

\subsubsection{Interaction effect:}

All interactions between intercropping and $\mathrm{N}$ mineral and nano particles fertilizer did not show significant effect on all studied traits in the first and second seasons.

\subsection{Soybean:}

Result in (Table4) show that number of pods, seed index, seed yield $\mathrm{kg} / \mathrm{fad}$ and straw yield ton/fad of soybean were significant, while plant height and number of fruiting branches/plant were not significantly affected by rate of $\mathrm{N}$ nano and mineral fertilizer in both seasons. The application of 50\% nano fertilizer $\mathrm{N}+50 \% \mathrm{~N}$ mineral fertilization of soybean gave the highest values of seed yield (534.98 \& $505.61 \mathrm{~kg} / \mathrm{fad})$ and straw yield $(1.89 \& 1.59$ ton/fad) in the two seasons, respectively, because increasing yield component. Whereas the application of $100 \% \mathrm{~N}$ mineral fertilization of soybean gave the lowest values of seed yield $(238.59 \& 209.24 \mathrm{~kg} / \mathrm{fad})$ and straw yield $(1.37 \& 1.07$ ton/fad $)$ in the both seasons, respectively. The nano-fertilizers have higher surface and reactive area it is mainly due to very less or smallest size of particles which provide more sites to facilitate different metabolic process in the plant system result production of more photosynthesis and intern more growth and yield (Meena et al., 2017 and Yasser et al.,2020). 
Table 4. Yield traits of intercropped soybean with maize as affected by different rates of $\mathrm{N}$ mineral and $\mathrm{N}$ nano fertilizer in 2018 and 2019 cropping seasons.

\begin{tabular}{|c|c|c|c|c|c|c|c|c|c|c|c|c|}
\hline \multirow{2}{*}{ Rate of fertilizer } & \multicolumn{2}{|c|}{ Plant height (cm) } & \multicolumn{2}{|c|}{$\begin{array}{l}\text { No of fruiting } \\
\text { branches/plant }\end{array}$} & \multicolumn{2}{|c|}{$\begin{array}{l}\text { No .of } \\
\text { pods/plant }\end{array}$} & \multicolumn{2}{|c|}{ Seed index (g) } & \multicolumn{2}{|c|}{$\begin{array}{l}\text { Seed yield } \\
(\mathrm{kg} / \mathrm{fad})\end{array}$} & \multicolumn{2}{|c|}{$\begin{array}{l}\text { Straw yield } \\
\text { ( ton /fad) }\end{array}$} \\
\hline & 2018 & 2019 & 2018 & 2019 & 2018 & 2019 & 2018 & 2019 & 2018 & 2019 & 2018 & 2019 \\
\hline $100 \% \mathrm{~N}$ mineral & 97.68 & 97.22 & 3.133 & 2.52 & 67.46 & 64.67 & 17.00 & 16.06 & 238.59 & 209.24 & 1.37 & 1.07 \\
\hline $100 \% \mathrm{~N}$ nano & 98.57 & 110.67 & 3.20 & 3.00 & 73.33 & 65.07 & 17.67 & 16.93 & 324.85 & 295.48 & 1.47 & 1.17 \\
\hline $\begin{array}{l}75 \% \text { Nnano }+25 \% \\
\mathrm{~N} \text { mineral }\end{array}$ & 105.17 & 112.67 & 3.21 & 3.53 & 73.60 & 66.92 & 18.00 & 17.30 & 435.83 & 406.46 & 1.57 & 1.20 \\
\hline $\begin{array}{l}50 \% \% \mathrm{~N} \text { nano+ } \\
50 \% \mathrm{~N} \text { mineral }\end{array}$ & 115.53 & 125.54 & 3.40 & 3.97 & 92.60 & 94.27 & 19.33 & 18.63 & 534.98 & 505.61 & 1.89 & 1.59 \\
\hline $\begin{array}{l}25 \% \text { Nnano }+75 \% \\
\text { Nmineral }\end{array}$ & 106.00 & 113.05 & 3.30 & 3.87 & 86.70 & 76.11 & 18.67 & 17.90 & 480.25 & 450.88 & 1.73 & 1.43 \\
\hline L.S.D $5 \%$ & N.s & N.s & N.s & $\mathrm{N}, \mathrm{s}$ & 15.70 & 13.32 & 1.23 & 1.32 & 95.60 & 95.60 & 0.42 & 0.52 \\
\hline \multicolumn{13}{|c|}{ Solid soybean ${ }^{\text {st }}$ season 1.282 ton/fad } \\
\hline \multicolumn{13}{|c|}{ Solid soybean ${ }^{\text {nd }}$ season 1.134 ton/fad } \\
\hline
\end{tabular}

\subsection{Groundnut:}

Data in Table (5) indicate that there was consistent and gradual increase in groundnut yield and its attributes with increasing the rate of nano nitrogen fertilization from $25 \%$ to $75 \% / \mathrm{fad}$. Differences were significant in both seasons for all traits in both seasons. Seed yield/fad behaved the same trend of yield components characters in both seasons, where application 50\% $\mathrm{N}$ nano along with $50 \%$ mineral fertilization increased seed yield by $60.82,60.70 \%$ in first and second seasons, respectively, compared to conventional fertilization. However, separately applied nano fertilization decreased seed yield/fad by $34.22,34.15 \%$ in the $1^{\text {st }}$ and $2{ }^{\text {nd }}$ seasons, respectively. The application of $50 \%$ nano fertilizer $\mathrm{N}+50 \% \mathrm{~N}$ mineral fertilization of groundnut gave the highest values of green yield $(47.33 \& 45.00$ ton/fad) in the two seasons, respectively. Whereas the application of $100 \% \mathrm{~N}$ mineral fertilization of groundnut gave the lowest values of green yield $(32.67 \& 32.00$ ton/fad) in the both seasons, respectively. If fertilizers use as nano form, it increases the availability of elements, may prevent $\mathrm{N}$ fixation and increased absorption and uptake through different plant parts (Hussein et al., 2015; Yessar et al., 2020). Results are in according to those obtained by (Manikandan \& Subramanian 2016 and Nagwa et al., 2019).

Table 5. Yield traits of intercropped groundnut with maize as affected by different rates of $\mathrm{N}$ mineral and $\mathrm{N}$ nano fertilizer in 2018 and 2019 cropping seasons.

\begin{tabular}{|c|c|c|c|c|c|c|c|c|c|c|c|c|}
\hline \multirow[t]{2}{*}{ Rate of fertilizer } & \multicolumn{2}{|c|}{$\begin{array}{l}\text { Plant height } \\
(\mathbf{c m})\end{array}$} & \multicolumn{2}{|c|}{$\begin{array}{c}\text { No of fruiting } \\
\text { branches/ } \\
\text { plant }\end{array}$} & \multicolumn{2}{|c|}{$\begin{array}{c}\text { No of } \\
\text { pods/plant }\end{array}$} & \multicolumn{2}{|c|}{ Seed index (g) } & \multicolumn{2}{|c|}{$\begin{array}{c}\text { pods yield } \\
(\text { ardab /fad })\end{array}$} & \multicolumn{2}{|c|}{$\begin{array}{l}\text { Green yield } \\
\text { ( ton /fad) }\end{array}$} \\
\hline & 2018 & 2019 & 2018 & 2019 & 2018 & 2019 & 2018 & 2019 & 2018 & 2019 & 2018 & 2019 \\
\hline $100 \% \mathrm{~N}$ mineral & 74.67 & 65.47 & 15.00 & 17.77 & 21.07 & 20.56 & 81.67 & 80.67 & 4.39 & 3.74 & 32.67 & 32.00 \\
\hline $100 \% \mathrm{~N}$ nano & 76.78 & 76.33 & 18.35 & 16.25 & 23.40 & 22.13 & 82.67 & 81.67 & 5.26 & 4.48 & 38.33 & 37.67 \\
\hline $\begin{array}{c}75 \% \mathrm{Nnano}+25 \% \\
\mathrm{~N} \text { mineral }\end{array}$ & 80.53 & 78.5 & 20.33 & 17.17 & 22.92 & 23.67 & 86.33 & 86.00 & 5.86 & 4.99 & 41.00 & 40.33 \\
\hline $\begin{array}{c}50 \% \% \mathrm{~N} \text { nano+ } \\
50 \% \mathrm{~N} \text { mineral }\end{array}$ & 84.45 & 81.23 & 23.00 & 20.20 & 28.67 & 30.23 & 94.00 & 90.67 & 7.06 & 6.01 & 47.33 & 45.00 \\
\hline $\begin{array}{c}25 \% \text { Nnano+ } \\
75 \% \text { Nmineral }\end{array}$ & 82.2 & 78.67 & 20.42 & 19.70 & 25.00 & 25.67 & 89.67 & 88.33 & 6.21 & 5.28 & 44.00 & 42.00 \\
\hline L.S.D $5 \%$ & 5.95 & 5.63 & 3.34 & 2.06 & 4.65 & 5.08 & 8.77 & 8.94 & 1.95 & 1.52 & 6.02 & 5.59 \\
\hline \multicolumn{13}{|c|}{ Solid groundnut ${ }^{\text {st }}$ season 11.75 ardab/fad } \\
\hline Solid groundnut ${ }^{n}$ & ${ }^{\text {nd }}$ season & 10.89 & $/ \mathrm{fad}$ & & & & & & & & & \\
\hline
\end{tabular}

\subsection{Sesame:}

Mean of plant height, length of fruiting zone, number of capsule/plant, seed index and seed yield ardab/fad were significantly affected by different fertilization treatments in the both seasons (Table 6). The results obviously indicated that $50 \% \mathrm{~N}$ nano + $50 \% \mathrm{~N}$ mineral treatment recorded the highest values of these characters, while application of $100 \%$ mineral alone had the lowest values and not suitable for application. Seed yield ardab/fad recorded the highest values were added application $50 \% \mathrm{~N}$ nano+50\% $\mathrm{N}$ mineralon sesame $(2.70 \& 3.39$ ardab/fad), while application $100 \%$ mineral alone was lowest values $(1.98 \& 2.21 \mathrm{ardab} / \mathrm{fad})$. These results may be attributed to nanomaterials are leading to significant improvement in plant through enhancing the growth and hence dry weight, leaf area and growth rate (Hasaneen et al., 2016). 
Table 6. Yield traits of intercropped sesame with maize as affected by different rates of $\mathbf{N}$ mineral and $\mathrm{N}$ nano fertilizer in 2018 and 2019 cropping seasons.

\begin{tabular}{|c|c|c|c|c|c|c|c|c|c|c|}
\hline \multirow[t]{2}{*}{$\begin{array}{l}\text { Rate of } \\
\text { fertilizer }\end{array}$} & \multicolumn{2}{|c|}{ Plant height (cm) } & \multicolumn{2}{|c|}{$\begin{array}{l}\text { Length of fruiting zone } \\
\text { (cm) }\end{array}$} & \multicolumn{2}{|c|}{$\begin{array}{c}\text { No .of capsule } \\
\text { /plant }\end{array}$} & \multicolumn{2}{|c|}{ Seed index (g) } & \multicolumn{2}{|c|}{$\begin{array}{c}\text { Seed yield } \\
\text { ( ardab } \\
\text { /fad) }\end{array}$} \\
\hline & 2018 & 2019 & 2018 & 2019 & 2018 & 2019 & 2018 & 2019 & 2018 & 2019 \\
\hline B1 & 145.33 & 151.57 & 93.33 & 87.67 & 66.73 & 75.12 & 3.53 & 3.3 & 1.98 & 2.12 \\
\hline B2 & 153.803 & 156.64 & 107.33 & 92.00 & 70.87 & 78.22 & 3.7 & 3.39 & 2.29 & 2.28 \\
\hline B3 & 167.67 & 163.67 & 114.50 & 96.61 & 73.38 & 79.63 & 3.92 & 3.8 & 2.46 & 2.59 \\
\hline B4 & 172.35 & 171.33 & 114.87 & 104.07 & 88.93 & 99.87 & 4.17 & 3.93 & 2.7 & 3.39 \\
\hline B5 & 162.67 & 166.67 & 107.97 & 103.52 & 84.6 & 83.2 & 4.08 & 3.88 & 2.59 & 2.83 \\
\hline L.S.D $5 \%$ & 18.38 & 17.54 & 10.54 & 11.34 & 14.99 & 14.37 & 0.28 & 0.29 & 0.37 & 0.36 \\
\hline Solid sesame & st season & $5.40 \mathrm{ard}$ & & & & & & & & \\
\hline Solid sesame & ${ }^{\text {nd }}$ season & 5.23 arda & & & & & & & & \\
\hline
\end{tabular}

The increases in these characters due to the combination between nano and mineral fertilization at different percent of its recommended could be attributed to nano fertilization increase availability of nutrient to the growing plant (Hediat \& Salama, 2012) and reduced losses of conventional $\mathrm{N}(\mathrm{Wu} \& \mathrm{Liu}$, 2008). Consequently, meristematic activity, stimulation of cell elongation and increased production. Application of foliar fertilizer is an effective way of correcting soil nutrient deficiencies, when soil applied fertilizers are not readily available or when plants are unable to absorb them directly from the soil (Manikandan \& Subramanian 2016).

Seed yield/fad of sesame gave the same trend of plant height, length of fruiting zone, no of capsules/plant. The increase in seed yield/fad due to applied $75 \% \mathrm{~N}$ nano of its recommended along with $25 \%$ mineral was 36.36 and $59.91 \%$ in first season and 17.90 and $48.68 \%$ in second season compared to conventional and nano only, respectively. These results may be attributed to nanomaterials are leading to significant improvement of plant through enhancing the growth and hence dry weight, leaf area and growth rate (Hasaneen et al., 2016).

\subsection{Competitive relationships:}

3.5.1. Land equivalent ratio (LER): Data presented in Table (7\&8) clearly indicated that land equivalent ratio in all treatments of the interaction between intercropped maize and $\mathrm{N}$ nano-mineral fertilization were greater than one in both seasons, which few exception indicating the advantageous to grow maize with each of soybean, groundnut and sesame in association than in solid culture. Intercropping groundnut with maize and using $75 \%$ nano fertilizer $+25 \%$ mineral fertilizers recorded the highest values for (LER) which was $1.72 \& 1,75$ in $1^{\text {st }}$ and $2^{\text {nd }}$ seasons, respectively. Intercropping soybean with maize with using $100 \%$ mineral fertilizer recorded the lowest values for (LER) which was $0.79 \& 0.87$ in the $1{ }^{\text {st }}$ and $2{ }^{\text {nd }}$ seasons, respectively. Similar results were obtained by Metwally et al., 2005a, band Toaima 2006. Who found that LER values were greater with intercropping system than sole crop of them.

Land equivalent coefficient (LEC) is a measure of interaction concerned with the strength of relationship.LEC is used for two -crop mixture the minimum expected productivity coefficient (PC) $25 \%$ that is a yield advantage is obtained if LEC value exceeded 0.25 . The effects of intercropping oil crops on maize and their interaction on the LEC of intercropping maize exceeded 0.25 in the intercrop combinations used intercropping 50\% groundnut with maize and $75 \%$ nano fertilizer recorded the highest values for LEC of 0.67 and 0.59in the ${ }^{\text {st }}$ and 2 nd seasons, respectively (Table7\&8). LEC values followed a trend similar to that of LER. This is consistent with findings of wafaa ${ }^{\text {et al., }} 2013$.

3.5.2. Effect of various cropping systems on competitive ratio $(\mathrm{CR})$ :

Data presented in Tables $(7 \& 8)$ revealed that the lowest values of CR were recorded for intercropping sesame with maize of 1.09 and 0.96 in the $1^{\text {st }}$ and 2 ${ }^{n d}$ seasons, respectively. However, the highest values of CR were recorded for intercropping soybean with maize at $100 \%$ Nano and 100\% mineral N1.77, 1.90 in the $1^{\text {st }}$ and $2^{\text {nd }}$ seasons, respectively. Similar results were recorded by Wafaa et al., 2013 and Nagwa et al., 2019.

3.5.3. Effect of various cropping systems on Aggressivity(Agg)

Data in Tables $(7 \& 8)$ show that aggressivity values of maize were positive, whereas values of soybean and groundnut intercrop were negative, meaning that maize was dominant and the two intercrops were 
Scientific Journal of Agricultural Sciences 2 (2): 90-103, 2020

Table 7. Competitive relationships and yield advantage for intercropping of soybean, groundnut and sesame with maize and fertilizer rates of maize on 2018 season.

\begin{tabular}{|c|c|c|c|c|c|c|c|c|c|c|c|c|}
\hline intercropping pattern & rat fertilizer & maize ardeb/fad & Intercrop. pattern & LERM & LERB & LER & LEC & $\mathrm{CR} \mathrm{m}$ & $\mathrm{CR} b$ & $\mathrm{CR}$ & Aggm & Aggb \\
\hline \multirow{5}{*}{$\begin{array}{l}M+50 \% \\
\text { Soybean }\end{array}$} & B1 & 14.833 & 239.59 & 0.61 & 0.19 & 0.79 & 0.11 & 1.59 & 0.09 & 1.68 & +0.34 & -0.34 \\
\hline & B2 & 21.36 & 324.85 & 0.87 & 0.25 & 1.13 & 0.22 & 1.69 & 0.09 & 1.77 & +0.53 & -0.53 \\
\hline & B3 & 27.07 & 534.98 & 1.11 & 0.42 & 1.52 & 0.46 & 1.30 & 0.11 & 1.41 & +0.38 & -0.38 \\
\hline & B4 & 25.22 & 435.83 & 1.03 & 0.34 & 1.37 & 0.35 & 1.48 & 0.10 & 1.58 & +0.51 & -0.51 \\
\hline & B5 & 20.767 & 480.25 & 0.85 & 0.37 & 1.22 & 0.32 & 1.11 & 0.13 & 1.24 & +0.13 & -0.13 \\
\hline \multirow[t]{3}{*}{ Mean } & & 21.85 & 403.1 & 0.89 & 0.31 & 1.21 & 0.28 & 1.39 & 0.11 & 1.50 & +0.38 & -0.38 \\
\hline & B1 & 18.917 & 4.39 & 0.77 & 0.37 & 1.15 & 0.29 & 1.01 & 0.15 & 1.16 & +0.02 & -0.02 \\
\hline & $\mathrm{B} 2$ & 21.51 & 5.26 & 0.88 & 0.45 & 1.33 & 0.39 & 0.96 & 0.15 & 1.11 & -0.05 & +0.05 \\
\hline \multirow{3}{*}{$\begin{array}{c}\mathrm{M}+50 \% \\
\text { Groundnut }\end{array}$} & B3 & 27.443 & 7.06 & 1.12 & 0.60 & 1.72 & 0.67 & 0.91 & 0.16 & 1.08 & +0.016 & -0.016 \\
\hline & B4 & 25.033 & 5.86 & 1.02 & 0.50 & 1.52 & 0.51 & 1.00 & 0.15 & 1.15 & -0.15 & +0.15 \\
\hline & B5 & 23.363 & 6.21 & 0.95 & 0.53 & 1.48 & 0.50 & 0.88 & 0.17 & 1.05 & -0.18 & +0.18 \\
\hline \multirow[t]{6}{*}{ Mean } & & 23.2532 & 5.756 & 0.95 & 0.49 & 1.44 & 0.47 & 0.95 & 0.15 & 1.10 & -0.07 & +0.07 \\
\hline & B1 & 14.833 & 2.00 & 0.61 & 0.37 & 0.98 & 0.22 & 0.80 & 0.18 & 0.99 & -0.22 & +0.22 \\
\hline & $\mathrm{B} 2$ & 21.137 & 2.29 & 0.86 & 0.42 & 1.29 & 0.37 & 1.00 & 0.15 & 1.15 & -0.003 & +0.003 \\
\hline & B3 & 24.477 & 2.7 & 1.00 & 0.50 & 1.50 & 0.50 & 0.98 & 0.15 & 1.13 & -0.02 & +0.02 \\
\hline & B4 & 22.25 & 2.46 & 0.91 & 0.46 & 1.36 & 0.41 & 0.98 & 0.15 & 1.13 & -0.02 & +0.02 \\
\hline & B5 & 20.767 & 2.59 & 0.85 & 0.48 & 1.33 & 0.41 & 0.87 & 0.17 & 1.04 & -0.19 & +0.19 \\
\hline Mean & & 20.693 & 2.408 & 0.85 & 0.45 & 1.29 & 0.38 & 0.93 & 0.16 & 1.09 & -0.09 & +0.09 \\
\hline $\begin{array}{l}\text { Solid maize } \\
\text { Solid soybean } \\
\text { Solid groundnut } \\
\text { Solid sesame }\end{array}$ & $\begin{array}{ll}24.48 & \text { ard } \\
1.282 & \text { ton/ } \\
11.75 & \text { ard } \\
5.40 & \text { ard }\end{array}$ & $\begin{array}{l}\text { b/fad } \\
\mathrm{fad} \\
\mathrm{b} / \mathrm{fad} \\
\mathrm{ab} / \mathrm{fad}\end{array}$ & & & & & & & & & & \\
\hline
\end{tabular}




\section{A.E., El-Karamity et al., 2020}

Table 8. Competitive relationships and yield advantage for intercropping of soybean, groundnut and sesame with maize and fertilizer rates of maize on 2019 season

\begin{tabular}{|c|c|c|c|c|c|c|c|c|c|c|c|c|}
\hline intercropping pattern & rat fertilizer & maize ardeb/fad & $\begin{array}{c}\text { intercropping } \\
\text { pattern }\end{array}$ & LERM & LERB & LER & LEC & $\mathrm{CR} \mathrm{m}$ & $\mathrm{CR} b$ & $\mathrm{CR}$ & Agg m & Agg b \\
\hline \multirow{5}{*}{$\begin{array}{l}\mathrm{M}+50 \% \\
\text { Soybean }\end{array}$} & B1 & 15.163 & 209.24 & 0.68 & 0.18 & 0.87 & 0.13 & 1.82 & 0.08 & 1.90 & +0.46 & 0.46 \\
\hline & B2 & 19.99 & 295.48 & 0.90 & 0.26 & 1.16 & 0.24 & 1.70 & 0.09 & 1.78 & +0.56 & -0.56 \\
\hline & B3 & 25.40 & 406.48 & 1.15 & 0.36 & 1.51 & 0.41 & 1.57 & 0.09 & 1.66 & +0.63 & -0.63 \\
\hline & B4 & 19.72 & 505.61 & 0.89 & 0.45 & 1.34 & 0.40 & 0.98 & 0.15 & 1.13 & -0.02 & +0.02 \\
\hline & B5 & 18.50 & 584.21 & 0.84 & 0.52 & 1.35 & 0.43 & 0.79 & 0.18 & 0.98 & -0.31 & +0.31 \\
\hline \multirow[t]{2}{*}{ Mean } & & 19.76 & 400.20 & 0.89 & 0.35 & 1.25 & 0.31 & 1.24 & 0.12 & 1.36 & +0.26 & -0.26 \\
\hline & B1 & 14.24 & 3.74 & 0.64 & 0.34 & 0.99 & 0.22 & 0.92 & 0.16 & 1.08 & -0.08 & +0.08 \\
\hline \multirow{4}{*}{$\begin{array}{c}\mathrm{M}+50 \% \\
\text { Groundnut }\end{array}$} & B2 & 19.13 & 4.48 & 0.86 & 0.41 & 1.28 & 0.36 & 1.03 & 0.14 & 1.17 & +0.04 & -0.04 \\
\hline & B3 & 28.55 & 4.99 & 1.29 & 0.46 & 1.75 & 0.59 & 1.38 & 0.11 & 1.49 & +0.54 & -0.54 \\
\hline & B4 & 23.17 & 6.01 & 1.05 & 0.55 & 1.60 & 0.58 & 0.93 & 0.16 & 1.09 & -0.11 & +0.11 \\
\hline & B5 & 22.98 & 5.28 & 1.04 & 0.48 & 1.52 & 0.50 & 1.05 & 0.14 & 1.19 & -0.08 & +0.08 \\
\hline \multirow[t]{2}{*}{ Mean } & & 21.61 & 4.90 & 0.98 & 0.45 & 1.43 & 0.44 & 1.06 & 0.14 & 1.20 & +0.09 & -0.09 \\
\hline & B1 & 11.79 & 2.12 & 0.53 & 0.41 & 0.94 & 0.22 & 0.64 & 0.23 & 0.87 & -0.43 & +0.43 \\
\hline \multirow{4}{*}{$\begin{array}{c}\mathrm{M}+50 \% \\
\text { Sesame }\end{array}$} & B2 & 19.65 & 2.28 & 0.89 & 0.44 & 1.32 & 0.39 & 1.00 & 0.15 & 1.14 & +0.01 & -0.01 \\
\hline & B3 & 21.76 & 2.58 & 0.98 & 0.49 & 1.48 & 0.48 & 0.98 & 0.15 & 1.13 & -0.02 & +0.02 \\
\hline & B4 & 18.98 & 3.39 & 0.86 & 0.65 & 1.51 & 0.56 & 0.65 & 0.23 & 0.87 & -0.68 & +0.68 \\
\hline & B5 & 14.83 & 2.83 & 0.67 & 0.54 & 1.21 & 0.36 & 0.61 & 0.24 & 0.85 & -0.64 & +0.64 \\
\hline \multicolumn{2}{|l|}{ Mean } & 17.40 & 2.64 & 0.79 & 0.50 & 1.29 & 0.40 & 0.76 & 0.19 & 0.96 & -0.35 & +0.35 \\
\hline \multicolumn{2}{|c|}{ Solid maize } & & & & 22.14 & ardab/fad & & & & & & \\
\hline \multicolumn{2}{|c|}{ Solid soybean } & & & & 1.134 & ton/fad & & & & & & \\
\hline \multicolumn{2}{|c|}{ Solid groundnut } & & & & 10.89 & ardab/fad & & & & & & \\
\hline \multicolumn{2}{|c|}{ Solid sesame } & & & & 5.23 & $\mathrm{ardab} / \mathrm{fad}$ & & & & & & \\
\hline
\end{tabular}


dominated. Those agrgressivity values of maize were negative when maize intercropping sesame in the two seasons. Similar results were recorded by Toaima 2006; Wafaa et al., 2013 and Nagwa et al.,2019.

3.5.4. Total returns and monetary advantage index (MAI):

The data of economic analysis as influenced by intercropping pattern and rate fertilization compared with solid planting of both crops are presented in Table $(9 \& 10)$. It reveals that the net

Table 9. Economic analysis of intercropping pattern and rates of $\mathrm{N}$ nano and mineral fertilize of maize on 2018 season.

\begin{tabular}{|c|c|c|c|c|c|c|c|c|c|}
\hline \multirow{2}{*}{$\begin{array}{l}\text { intercropping } \\
\text { pattern }\end{array}$} & \multirow{2}{*}{$\begin{array}{c}\text { Rat } \\
\text { fertilizer }\end{array}$} & \multicolumn{2}{|c|}{ Crops yield } & \multicolumn{2}{|c|}{$\begin{array}{l}\text { Total income } \\
\text { (LE /fad) }\end{array}$} & \multirow{2}{*}{$\begin{array}{c}\text { Total } \\
\text { income } \\
\text { (LE/fad) }\end{array}$} & \multirow{2}{*}{$\begin{array}{c}\text { Total } \\
\text { expenditure } \\
\text { (LE/fad) }\end{array}$} & \multirow{2}{*}{$\begin{array}{c}\text { Net } \\
\text { profit } \\
(\mathrm{LE} / \mathrm{fad})\end{array}$} & \multirow{2}{*}{ MAI } \\
\hline & & $\begin{array}{l}\text { Maize } \\
\text { ardab } \\
\end{array}$ & intercropping $\mathrm{F}$ & maize & $\begin{array}{l}\text { intercropping } \\
\text { pattern }\end{array}$ & & & & \\
\hline \multirow{5}{*}{$\begin{array}{l}\mathrm{M}+50 \% \\
\text { soybean }\end{array}$} & B1 & 14.833 & 239.59 & 7.1198 & 1.677130 & 8.79693 & 7.775 & 1.0219 & 0.128 \\
\hline & $\mathrm{B} 2$ & 21.36 & 324.85 & 10.253 & 2.273950 & 12.52695 & 7.015 & 5.5120 & 4.650 \\
\hline & B3 & 27.07 & 534.98 & 12.994 & 3.744860 & 16.73886 & 7.385 & 9.3539 & 8.692 \\
\hline & B4 & 25.22 & 435.83 & 12.106 & 3.050810 & 15.15681 & 7.705 & 7.4518 & 6.706 \\
\hline & B5 & 20.767 & 480.25 & 9.9682 & 3.361750 & 13.32995 & 7.075 & 6.2550 & 5.514 \\
\hline \multirow[t]{2}{*}{ Mean } & & 21.85 & 403.1 & 10.488 & 2.821700 & 13.3097 & 7.391 & 5.9187 & 5.119 \\
\hline & B1 & 18.917 & 4.39 & 9.0802 & 5.268 & 14.3482 & 8.160 & 6.1882 & 5.178 \\
\hline \multirow{4}{*}{$\begin{array}{l}\text { M+50\% } \\
\text { groundnut }\end{array}$} & B2 & 21.51 & 5.26 & 10.325 & 6.312 & 16.637 & 7.400 & 9.2370 & 8.456 \\
\hline & B3 & 27.443 & 7.06 & 13.1726 & 8.472 & 21.6446 & 7.770 & 13.8746 & 13.303 \\
\hline & B4 & 25.033 & 5.86 & 12.0158 & 7.032 & 19.0478 & 8.090 & 10.9578 & 10.333 \\
\hline & B5 & 23.363 & 6.21 & 11.2142 & 7.452 & 18.6662 & 7.460 & 11.2062 & 10.548 \\
\hline \multirow[t]{2}{*}{ Mean } & & 23.2532 & 5.756 & 11.1615 & 6.907 & 18.0685 & 7.776 & 10.2925 & 9.593 \\
\hline & B1 & 14.833 & 2 & 7.1198 & 6.000 & 13.1198 & 7.635 & 5.4848 & 4.421 \\
\hline \multirow{4}{*}{$\begin{array}{l}\mathrm{M}+50 \% \\
\text { Sesame }\end{array}$} & B2 & 21.137 & 2.29 & 10,1458 & 6.870 & 101464.9 & 6.875 & 3.2720 & 2.514 \\
\hline & B3 & 24.477 & 2.7 & 11.7490 & 8.100 & 19.849 & 7.245 & 12.6040 & 11.928 \\
\hline & B4 & 22.25 & 2.46 & 10.680 & 7.380 & 18.06 & 7.565 & 10.4950 & 9.833 \\
\hline & B5 & 20.767 & 2.59 & 9.9682 & 7.770 & 17.7382 & 6.935 & 10.8032 & 9.977 \\
\hline \multicolumn{2}{|l|}{ Mean } & 20.693 & 2.408 & 9.9326 & 7.224 & 17.1566 & 7.251 & 9.9056 & 9.130 \\
\hline \multicolumn{2}{|c|}{ Solid Maize } & \multicolumn{2}{|r|}{24.48} & 11.750 & & & 7.535 & 4.215 & 4.215 \\
\hline \multicolumn{2}{|c|}{ Solid soybean } & \multicolumn{2}{|r|}{1282} & 8.974 & & & 5.798 & 3.176 & 3.176 \\
\hline \multicolumn{2}{|c|}{ Solid groundnut } & \multicolumn{2}{|r|}{11.75} & 14.100 & & & 7.266 & 6.834 & 6.834 \\
\hline \multicolumn{2}{|c|}{ Solid sesame } & & 5.4 & 16.200 & & & 6.272 & 9.928 & 9.928 \\
\hline
\end{tabular}

profit of using $75 \%$ Nano plus $25 \%$ mineral $\mathrm{N}$ fertilizer for maize and groundnut intercrop recorded $13.875 \& 11.922$ L.E. fad. While The monetary advantage index (MAI) recorded $13.303 \& 11.35$ L.E. fad, meanwhile, the lowest net return was recorded for intercropping soybean with maize received rate of $100 \%$ mineral fertilizer $1.022 \& 0.968$ L.E. fad and monetary advantage index (MAI) of $0.128 \& 0.181$ L.E. fad in the $1^{\text {st }}$ and $2^{\text {nd }}$ successive seasons respectively.

L.E 480 for ardab of maize L.E 7000 for ton of soybean $\quad$ L.E 1200 for ardab groundnut L.E 3000 for ardab sesame.

\section{Conclusion}

Intercropping of oil crops with maize showed money benefits and intercropping maize- legumes are produced greater seed yield than either crops grown alone. In addition, land use efficiency greater LER than sole crops. Intercropping oil crops with maize increases the cultivated area of them, which reduces the gap between production and consumption to obtain self-sufficiency and to using the residues of both soybeans and groundnut as animal feed., the legume crops enhance land fertility through the natural nitrogen fixed by legume crops. More than less, using Nano $\mathrm{N}$ fertilizer is a profitable component in agricultural practices as it has a rapid impact on plant. So, the pattern of maize-groundnut intercrop fertilized with $75 \%$ Nano $\mathrm{N}$ fertilizer plus $25 \%$ mineral $\mathrm{N}$ fertilizer of the recommended is very important to make maize more profitable for farmer. 
Table 10. Economic analysis of intercropping pattern and rates of $\mathrm{N}$ nano and mineral fertilize of maize on 2019 season.

\begin{tabular}{|c|c|c|c|c|c|c|c|c|c|}
\hline \multirow{2}{*}{$\begin{array}{c}\text { Intercropping } \\
\text { Pattern }\end{array}$} & \multirow{2}{*}{$\begin{array}{l}\text { Rat } \\
\text { fertilizer }\end{array}$} & \multicolumn{2}{|c|}{ Crops yield } & \multicolumn{2}{|c|}{$\begin{array}{l}\text { Total income } \\
(\mathrm{LE} / \mathrm{fad})\end{array}$} & \multirow{2}{*}{$\begin{array}{c}\text { Total } \\
\text { income } \\
\text { (LE/fad) }\end{array}$} & \multirow{2}{*}{$\begin{array}{c}\text { Total } \\
\text { expenditure } \\
\text { (LE/fad) }\end{array}$} & \multirow{2}{*}{$\begin{array}{c}\text { Net } \\
\text { profit } \\
(\mathrm{LE} / \mathrm{fad})\end{array}$} & \multirow{2}{*}{ MAI } \\
\hline & & maize & $\begin{array}{r}\text { intercropp } \\
\text { patteren }\end{array}$ & Maize & $\begin{array}{c}\text { intercropping } \\
\text { patteren }\end{array}$ & & & & \\
\hline \multirow{5}{*}{$\begin{array}{l}\mathrm{M}+50 \% \\
\text { soybean }\end{array}$} & B1 & 15.163 & 209.24 & 7.278 & 1.465 & 8.743 & 7.775 & 0.968 & 0.181 \\
\hline & $\mathrm{B} 2$ & 19.99 & 295.48 & 9.595 & 2.068 & 11.663 & 7.015 & 4.648 & 3.786 \\
\hline & B3 & 25.40 & 406.48 & 12.192 & 2.845 & 15.037 & 7.385 & 7.652 & 6.990 \\
\hline & B4 & 19.72 & 505.61 & 9.465 & 3.539 & 13.004 & 7.705 & 5.299 & 4.553 \\
\hline & B5 & 18.50 & 584.21 & 8.880 & 4.089 & 12.969 & 7.075 & 5.894 & 5.153 \\
\hline \multirow[t]{2}{*}{ Mean } & & 19.76 & 400.20 & 9.485 & 2.801 & 12.286 & 7.391 & 4.895 & 4.095 \\
\hline & B1 & 14.24 & 3.74 & 6.835 & 4.488 & 11.323 & 8.160 & 3.163 & 2.153 \\
\hline \multirow{4}{*}{$\begin{array}{c}\mathrm{M}+50 \% \\
\text { groundnut }\end{array}$} & $\mathrm{B} 2$ & 19.13 & 4.48 & 9.182 & 5.376 & 14.558 & 7.400 & 7.158 & 6.377 \\
\hline & B3 & 28.55 & 4.99 & 13.704 & 5.988 & 19.692 & 7.770 & 11.922 & 11.351 \\
\hline & B4 & 23.17 & 6.01 & 11.122 & 7.212 & 18.334 & 8.090 & 10.244 & 9.619 \\
\hline & B5 & 22.98 & 5.28 & 11.030 & 6.336 & 17.366 & 7.460 & 9.906 & 9.248 \\
\hline \multirow[t]{2}{*}{ Mean } & & 21.61 & 4.90 & 10.373 & 5.880 & 16.253 & 7.776 & 8.477 & 7.778 \\
\hline & B1 & 11.79 & 2.12 & 5.659 & 6.360 & 12.019 & 7.635 & 4.384 & 3.320 \\
\hline$M+50 \%$ & $\mathrm{~B} 2$ & 19.65 & 2.28 & 9.432 & 6.840 & 16.272 & 6.875 & 9.397 & 8.639 \\
\hline \multirow[t]{3}{*}{ Sesame } & B3 & 21.76 & 2.58 & 10.445 & 7.740 & 18.185 & 7.245 & 10.94 & 10.264 \\
\hline & B4 & 18.98 & 3.39 & 9.110 & 10.170 & 19.28 & 7.565 & 11.715 & 11.053 \\
\hline & B5 & 14.83 & 2.83 & 7.118 & 8.490 & 15.608 & 6.935 & 8.673 & 7.847 \\
\hline \multirow[t]{5}{*}{ Mean } & & 17.40 & 2.64 & 8.352 & 7.920 & 16.272 & 7.251 & 9.021 & 8.246 \\
\hline & 22.14 & $/$ fad & 10.627 & & & 7.535 & 3.092 & & \\
\hline & 1.134 to & $1 /$ fad & 7.938 & & & 5.798 & 2.14 & & \\
\hline & 10.89 & $\mathrm{~b} / \mathrm{fad}$ & 13.068 & & & 7.266 & 5.802 & & \\
\hline & 5.23 & $\mathrm{~b} / \mathrm{fad}$ & 15.690 & & & 6.272 & 9.418 & & \\
\hline
\end{tabular}

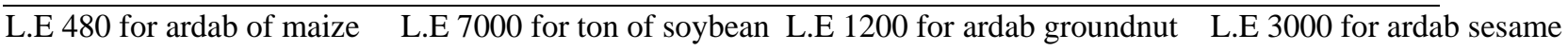

\section{REFRENCES}

Adetiloye PO, Ezedinma FOC, Okigbo BN (1983).

A Land equivalent coefficient concept for the evaluation of competitive and productive interactions on simple complex mixtures. Ecol.Modelling.,19:2739.

Adu-Gyamfi JJ, Myaka FA, Sakala WD, Odgaard R, Vesterager JM, Høgh-Jensen H. (2007). Biological Nitrogen Fixation and Nitrogen and Phosphorus Budgets in Farmer-Managed Intercrops of Maize-Pigeonpea in Semi-arid Southern and Eastern Africa. Plant and Soil. 295(1-2): 127-136. Agriculture Statistical (2017). Winter Crops. Agriculture Statistical and Economic Sector.1 st Ed., Ministry of Agriculture and Land Reclamation, Egypt.

Agriculture Statistical (2018). Summer \& Nile Crops. Agriculture Statistical and Economic Sector.2nd Ed., Ministry of Agriculture and Land Reclamation, Egypt.

Ahmed S, NigerF,Kabir M, Chakrabarti G,NurH,Imamul Huq H(2012). Development of Slow Release Nano Fertilizer. Proceedings of the InternationalWorkshop on Nanotechnology, Dhaka, Bangladesh.Biological Agriculture and Horticulture.
Alam SMN, Salim M, Islam N,Rahman MN (2007).International Journal of Sustainability. In Crop Production 2(6) 31-33.

Anjuman AR, Farah N, Samina A, Imamul SMH (2016). Synthesis of nitrogen nano fertilizer and its efficacy. Canadian J., of Pure and Applied Sci.,10(2):3913-3919.

Alpha yK, TOFAA, AdemulegunT, SolomonR, ShehuH, KamaiN, OmoiguiL(2017).MaizeSoybean intercropping sustainable intensification of cereal-legume cropping systems in Northern Nigeria. Experimental Agriculture (3):1-15.

FAO (2016). Food and Agriculture Organization of the United Nations. Giews country briefs. [http://www.fao.org/faostat/en/\#data/QC]

Freed RD (1991). MSTATC Microcomputer Statistical Program. Michigan State Univ., East Lansing, Michigan, USA.

Hasaneen M,Abdel-AzizH, OmerA (2016).Effect of foliar application of engineered nanomaterials: carbo nanotubes NPK and chitosan nanoparticles NPK fertilizer on the growth of French bean plant. Biochemistry and Biotechnology Research, 4(4): 6876.

Hediat M,SalamaA (2012).Effects of nanoparticles in some crop plants, Common bean (Phaseolus 
vulgaris L.) and corn (Zea mays L.). Inter. Res. J. Biote. 3(10):190-197.

Ijoyah MO,IorlamenT,FanenFT (2014). Yield Evaluation of Three Sesame (Sesamum indicum L.) Varieties Intercropped with Maize (Zea mays L.) in a Southern Guinea Savannah Location, Nigeria. International Letters of Natural Sciences. (18);36-46 Godwin AA,Egbe MO (2014). Bambara groundnut/maize intercropping: Effects of planting densities in Southern guinea savanna of Nigeria.African J., of Agric., Res., 9(4): 479-486.

Kafiriti EM,Deckers J (2001). Sesame, in crop production in Tropical Africa. DGIC: Ministry of Foreign Affairs, External Trade and International Cooperations, Brussels, Belgium, Raw markers, R.H. (ed):797-803.

Kling JG,Edmeades G (1997). Morphology and growth of maize. Research guide No. 9 Training programme. International Institute of Tropical Agriculture (IITA)Ibadan, Nigeria, pp. 3-6.

Mc-Gilchrist CA (1965). Analysis of competition on experiments biometrics .21975- 985 .

Metally AA, ShafikMM,EIMorshedy WA,Aly HR(2005a). Yield and Land Equivalent Ratios of intercropped maize and soybean.Proceed. $1^{\text {st }}$ Sci.Conf.Cereal Crops.Alex.Egypt.113-120.

Metally AA,MohamedGO,Sherif MN,AwadMM (2005b). Yield and Land Equivalent Ratios of intercropped maize and groundnut- The 11 th Conf. Egypt ion Soc. Crops Sci, Assuit, Egypt.163-173.

Meena DS, Gautam C, Patldar OP, Meena HM, Prakasha G, Vishwajith(2017). No fertilizer is a new way to increase nutrients use efficiency in crop production. International J., of Agric., Sci., 9(7): 3831-3833.

Michael K, Franke AC, Adjei-Nsiah S, Ahiabor BDK, Abaidoo R, Giller KE (2017). Maize-grain legume intercropping for enhanced resource use efficiency andcrop productivity in the Guinea savanna of northern Ghana. Field CropRes.,213:3850.

Mkamilo GS (2004). Maize-sesame intercropping in Southeast Tanzania: Farmers'practices and perceptions, and intercrop performance. $\mathrm{PhD}$ Thesis, Wageningen University, The Netherlands, 112 pp., with English and Dutch summaries.

Mohamed MA (2007). Production of corn and groundnut under solid and intercropping systems. M.Sc., Fac. Agric., Cairo Univ., Egypt.

Manikandan A, Subramanian KS (2016). Evaluation of zeolite based nitrogen nano-fertilizers on maize growth, yield and quality on inceptisols and alfisols. Inter. J. Plant Soil Sci. 9(4), 1-9.

Nagwa RA, Ahmed MS, Hamd-Alla WA (2019). Effect of intercropping of some legume forage crops under levels of mineral NPK and nano NPK fertilizer.
J. of Plant Production, Mansoura Univ., 10 (10):833 842.

Rameshaiah G.N.; J. Pallavi and S. Shabnam. (2015). Nano fertilizers and nano sensors - an attempt for developing smart agriculture. Int. J. Eng. Res. Gener. Sci.3: 314-320.

Suppan S (2017). Applying Nanotechnology to Fertilizer: Rationales, research, risks and regulatory challenges. The Institute for Agriculture and Trade Policy works locally and globally. This article originated as a presentation in Spanish via Skype to an international seminar of the Brazilian Research Network on Nanotechnology, Society and Environment. 21pp. Brazil.

Sekhon BS (2014). Nanotechnology in agri-food production: an overview. Nanotech Sci Appl.; 31-53.

Siddiqui MH, Al-WhaibiMH, FirozM, AlKhaishany MY (2015). Role of nano particles in plants. In: Nanotechnology and Plant Sciences. Springer International Publishing; 19-35.

Steel RGD, Torrie JA (1980). Procedures of statistics, 2nd edition, Mc Graw-Hill Book company. Sherif SA,ZohryAA, Ibrahimi S(2005).Effect of planting dates and densities of maize intercropping with groundnut on growth, yield and yield components of both crops.Arab Univ. J. Agric. Sci. Ain Shams Univ.,Cairo.13(3):771-791.

SherifIE(2010).Growing soybean with maize under different intercropping patterns and high population densities.Ph.D.Fac. Agric., Cairo Univ.,Egypt.

Toamia SEA (2006). Effect of intercropping soybean, cowpea and guar with maize on yield and its components. J.Agric. Sci. Mansoura Univ., 31(1):5570.

Wafaa KhM, Nagwa RA, Abdl-El-Hakim WM (2013). Effect of intercropping, dates of sowing and $\mathrm{N}$ fertilizers on growth and yield of maize and tomato. Egypt. J. of Appl.Sci., 28(12B):625-644.

Willey RW (1979). Intercropping-its importance and research needs part.1- competition and yield advantage Field Crop Res., 32:1-10.

Willey RW, Rao MR (1980). Competitive ratio for quantifying competition between intercrops. Exp.Agric. 16:117-125.

Wu L, Liu MZ (2008). Preparation and properties of chitosan-coated NPK compound fertilizer with controlled-release and water-retention. Carbohydr. Polym. 72(2), 240-247. Field Crop Res. 198, 269279.

Yasser E.E, Amira A.E, Kamal AE (2020). Influence of Intercropping Cowpea with some Maize Hybrids and $\mathrm{N}$ Nano-Mineral Fertilization on Productivity in Salinity Soil. Egypt. J. Agron. ,42(1):63:78.

Yu Y, StomphT, MakowskiD, Zhang L, van der Werf W (2016). A meta-analysis of relative crop yields in cereal/legume mixtures suggests options for management. 


\title{
A.E., El-Karamity et al., 2020
}

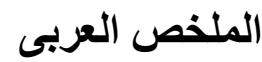

\section{تحميل بعض محاصيل الزيت الصيفيه مع الذرة الشامية تحت مستويات من التسميل النيتروجينى النانو و المعدنى}

\author{
*عبد الحميد السيد القراميطى،* نجوى رفعت أحمد و* أيه نتعى محمد
}

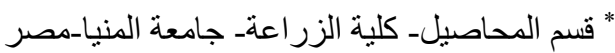

**قم بحوث التتكيف المحصولى - معهد بحوث المحاصيل الحقلية ـ مركز البحوث الرز العية ـ الجيزة ـ مصر

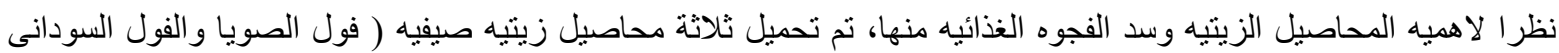

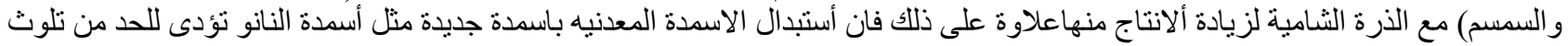

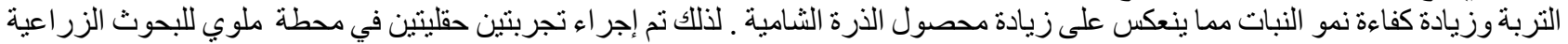

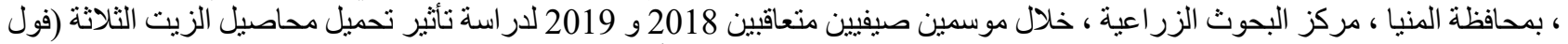

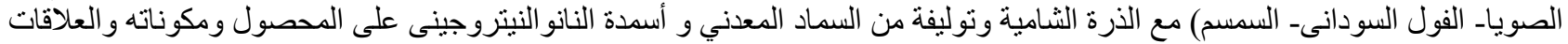
التنافسية لكل منهم.

أستخدم تصميم القطع المنشقة مرة واحدة فى ثلاث مكررات. تم تخصيص القطع الرئيسية للمحاصيل الزيتيه: فول الصويا و الفول

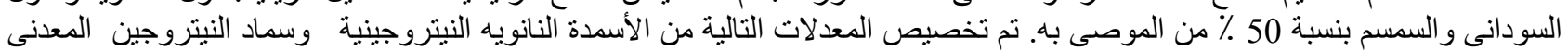

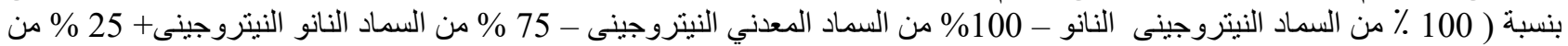

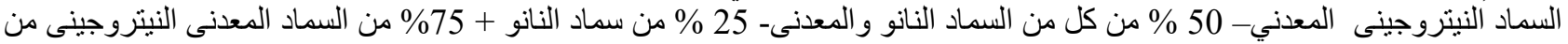

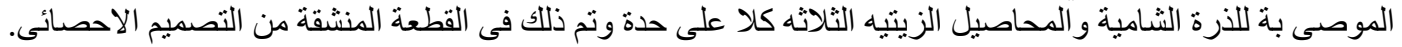

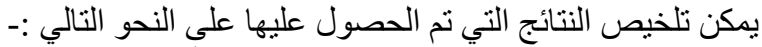

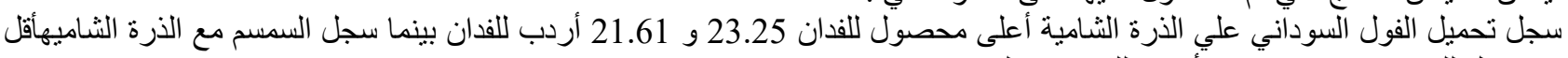
محصول للذره 20.69 و 17.40أردب للفئل اللفان في الموسمين.

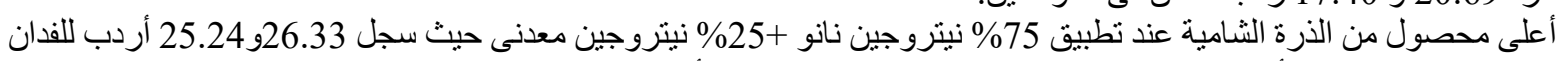

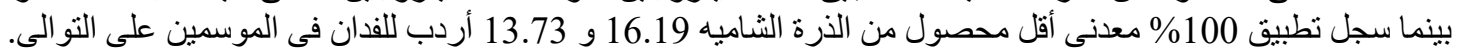

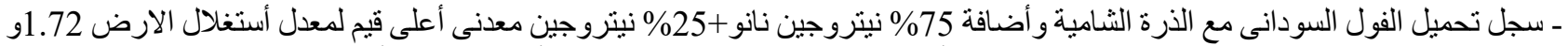

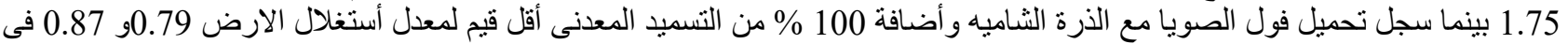

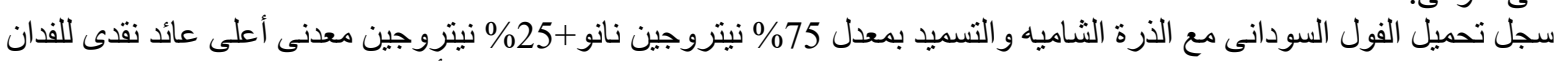

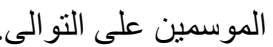

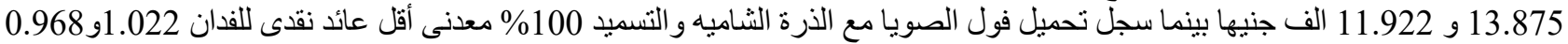

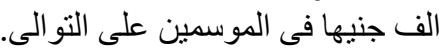

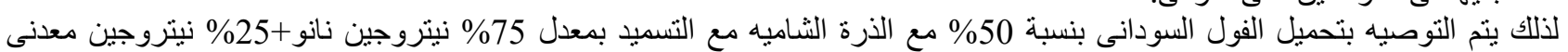

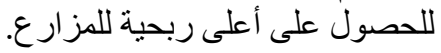

